\title{
HUBUNGAN DUKUNGAN KELUARGA DENGAN KEMANDIRIAN PASIEN STROKE DI INSTALASI REHABILITASI MEDIK RUMAH SAKIT DR. ISKAK TULUNGAGUNG
}

\author{
Setyoadi ${ }^{*} \bowtie$, Tina Handayani Nasution ${ }^{*}$, Amanda Kardinasari ${ }^{*}$
}

\begin{abstract}
Abstrak
Pasien stroke tidak dapat sepenuhnya mandiri disebabkan adanya gejala sisa yang menyertai setelah perawatan akut. Keluarga sangat berperan dalam fase pemulihan, sehingga sejak awal perawatan keluarga diharapkan terlibat dalam penanganan penderita. Penelitian ini bertujuan untuk mengetahui hubungan dukungan keluarga dengan kemandirian pasien stroke di instalasi rawat jalan rehabilitasi medik Rumah Sakit Dr. Iskak Tulungagung. Penelitian ini adalah penelitian deskriptif dengan pengambilan sample secara purposive sampling dengan jumlah sample 57 pasien. Pengambilan data dilakukan dengan menggunakan kuesioner Barthel index dan kuesioner dukungan keluarga. Berdasarkan hasil analisis data didapatkan dukungan keluarga skor rata-rata adalah 87,84 termasuk kategori baik. Sementara skor rata-rata kemandirian pasien stroke adalah 81,75 termasuk kategori sesang. Hasil uji statistik menunjukkan nilai signifikasi $p=0,00(a=0,05)$. Kesimpulan dari penelitian ini adalah terdapat hubungan antara dukungan keluarga dengan kemandirian. Berdasarkan hasil penelitian ini disarankan petugas kesehatan dapat melibatkan peran keluarga dalam proses pemulihan pada pasien pasca stroke yang menjalani perawatan di rumah.
\end{abstract}

Kata kunci: dukungan keluarga, kemandirian, stroke

\section{THE CORRELATION OF FAMILY SUPPORT WITH STROKE PATIENTS' INDEPENDENCE AT MEDICAL REHABILITATION CENTER OF DR. ISKAK HOSPITAL TULUNGAGUNG}

\begin{abstract}
Stroke patients cannot fully support themselves after acute care. During the recovery phase, family plays an important role, they served as a source of support even during the healing and rehabilitation phase. The purpose of this study is to identify the correlation of family support with stroke patients' independence in the medical rehabilitation center of Dr. Iskak hospital Tulungagung. It is a descriptive research that use purposive sampling method. The research data were collected by using Barthel Index's Instrument and family support instrument. Based on the results of the study, out of 57 respondents, the average score for family support was 87,84 while the stroke patients' independence receives an average score of 81,75 . Statistical analysis showed significant value $p=0.00(a=0.05)$ In conclusion, by giving a better family support the stroke patients can gradually become more independent. It is advised that the paramedics should improve their role in providing education about the importance of family support towards stroke patients' family during the recovery process at home.
\end{abstract}

Keywords: family support, independent, stroke

* Program Studi IImu Keperawatan, FK UB

E-mail: setyoadimalang@gmail.com 


\section{Pendahuluan}

Stroke adalah keadaan yang muncul ketika pembuluh darah otak gagal mensuplai oksigen ke sel-sel otak. ${ }^{1}$ Sel otak akan rusak ketika tidak menerima oksigen dan nutrisi dari darah. Gejala stroke terjadi secara tiba-tiba yaitu; kelemahan pada satu sisi tubuh, kebingungan, kesulitan berbicara atau memahami pembicaraan, masalah penglihatan, kesulitan berjalan, kehilangan keseimbangan dan sakit kepala. ${ }^{2}$

Menurut BKKBN (2009), penyakit stroke dan jantung dahulu dianggap sebagai penyakit degeneratif yaitu penyakit untuk usia di atas 60 tahun. ${ }^{3}$ Saat ini stroke dapat terjadi pada usia berapapun dengan $75 \%$ terjadi pada usia di atas 65 tahun dan hampir $25 \%$ terjadi pada usia di bawah 65 tahun. Meningkatnya kejadian stroke pada individu usia 20 hingga 25 tahun berdampak terhadap menurunnya tingkat produktivitas. ${ }^{4}$

WHO (2011) menyebutkan terdapat 15.000 .000 orang yang di dunia mengalami stroke setiap tahunnya. ${ }^{5}$ Pada tahun 2010 , prevalensi stroke di seluruh dunia adalah 33 juta jiwa, dengan 16,9 juta jiwa mengalami stroke untuk pertama kali. Dari jumlah tersebut, 5 juta jiwa meninggal dan 5 juta jiwa mengalami cacat. ${ }^{6}$ Secara umum, stroke merupakan penyebab utama kedua kematian di negara-negara maju dengan 4,5 juta kematian setiap tahun. ${ }^{1}$

Gangguan fungsi akibat stroke secara langsung menyebabkan gangguan kecacatan fisik, peningkatan beban ekonomi, beban perawatan di keluarga, penurunan kualitas hidup, dan peningkatan mortalitas. Stroke merupakan penyebab utama kecacatan pada orang dewasa. Prevalensi kecacatan akibat stroke diperkirakan sekitar 33-460 per 100.000 jiwa. ${ }^{6}$ Penderita stroke yang bertahan hidup dengan kecacatan merupakan beban ekonomi bagi keluarga dan sistem asuransi kesehatan. Biaya pengobatan dan rehabilitasi pasca stroke mencapai US\$ 140.000/pasien atau sekitar 1,4 millar rupiah/pasien. ${ }^{7}$

Penelitian Cameron et al (2014), sebanyak $50 \%$ dari penderita stroke mengalami kesulitan melakukan aktivitas, termasuk mandi, jalan kaki, naik tangga, melakukan pekerjaan rumah tangga, menyiapkan makanan dan bepergian. ${ }^{8}$ Penderita stroke tidak dapat mandiri dan memerlukan bantuan dalam pemenuhan kebutuhan sehari-hari. Sepertiga dari penderita stroke memerlukan perawatan lanjutan minimal selama 3 bulan untuk meningkatkan kemampuan mandiri. ${ }^{9}$

Kemandirian adalah kemampuan untuk memenuhi kebutuhan diri sendiri. Kemandirian mengandung pengertian suatu keadaan dimana seseorang yang memiliki hasrat bersaing untuk maju demi kebaikan dirinya, mampu mengambil keputusan dan inisiatif untuk mengatasi masalah yang dihadapi, memiliki kepercayaan diri dalam mengerjakan tugas-tugasnya, bertanggung jawab terhadap apa yang dilakukan. ${ }^{10}$ Pasien stroke tidak dapat sepenuhnya mandiri, sehingga membutuhkan bantuan orang lain atau anggota keluarga. ${ }^{11}$ Perawat memiliki peran penting untuk memberikan asuhan keperawatan yang berfokus pada proses rehabilitasi dengan cara menggunakan pendekatan upaya promotif dan preventif untuk mencegah kecacatan lebih lanjut.Upaya pencegahan (preventif) dilakukan untuk mengendalikan serangan ulang dan mencegah kecacatan. Upaya promotif untuk meningkatkan kualitas hidup pasien stroke dan keluarga yang memberikan perawatan di rumah. ${ }^{12}$

Rehabilitasi pada pasien stroke bertujuan untuk memperbaiki mobilitas dan pencapaian perawatan diri secara mandiri oleh pasien. ${ }^{13}$ Kepatuhan pasien stroke mematuhi dalam rehabilitasi memerlukan dukungan keluarga untuk mencapai hasil fungsional yang maksimal. Keluarga sangat berperan dalam fase pemulihan ini, sehingga 
sejak awal perawatan keluarga diharapkan terlibat dalam penanganan penderita. ${ }^{11}$

Sasaran subjek proses rehabilitasi pada pasien stroke adalah pasien dan keluarga. Proses penyembuhan dan rehabilitasi pasien stroke dapat terjadi dalam waktu lama, yang membutuhkan kesabaran dan ketekunan pasien dan keluarga. Dalam masa rehabilitasi seringkali pasien stroke malas untuk melakukan latihan dalam menjaga mobilitas seperti melakukan latihan rentang gerak, maka dari itu sangat diperlukan dukungan dari keluarga untuk memberikan pengertian kepada pasien dan melatih serta membantu pasien untuk selalu melakukan latihan rentang gerak. ${ }^{13}$

Keluarga memiliki peran penting; yaitu mampu mengenal masalah kesehatan, mengambil keputusan untuk mengambil tindakan yang tepat bagi keluarga, memberikan perawatan kepada anggota keluarga yang sakit, yang tidak dapat membantu diri karena cacat atau umur terlalu muda, mempertahankan suasana rumah yang menguntungkan untuk kesehatan dan perkembangan kepribadian dan pemanfaatan fasilitas kesehatan yang ada. ${ }^{14}$ Peran keluarga memberikan bantuan selama masa penyembuhan dan pemulihan klien. Dukungan keluarga yang besar dapat meningkatkan keberhasilan rehabilitasi, penyembuhan atau pemulihan. ${ }^{15}$

Berdasarkan hasil studi pendahuluan, pasien stroke rawat jalan di instalasi rehabilitasi medik rumah sakit Dr. Iskak Tulungagung mencapai 709 pada tahun 2014. Rumah sakit mencatat stroke merupakan penyakit urutan ke-4 di instalasi rawat jalan rehabilitasi medik. Ketika pasien datang, pasien selalu ditemani dengan keluarga, karena keterbatasan yang dimiliki. Hasil wawancara terhadap 5 keluarga yang sedang berkunjung ke rehab medik mengatakan mengalami kesulitan untuk membantu memenuhi kebutuhan dan tidak tahu apa yang seharusnya dilakukan oleh keluarga. Berdasarkan fenomena tersebut perlu adanya penelitian yang melihat hubungan antara dukungan keluarga dan tingkat kemandirian pasien stroke.

\section{Bahan dan Metode}

Penelitian ini menggunakan desain penelitian deskriptif korelasional dengan metode pendekatan cross sectional. Populasi dalam penelitian ini adalah seluruh penderita pasien stroke di Instalasi Rehabilitasi Medik Rumah Sakit Dr. Iskak Tulungagung. Besar sampel dalam penelitian ini adalah sebanyak 57 responden yang diambil dengan cara purposive sampling.

Pada penelitian ini, variabel independen adalah dukungan keluarga pada pasien stroke. Variabel dependen adalah kemandirian pada pasien stroke. Alat ukur yang digunakan adalah kuisioner. Lembar kuesioner variabel independen terdiri dari 25 pertanyaan, sedangkan variabel dependen terdiri dari 10 pertanyaan. Kategori penilaian dukungan keluarga yaitu $<55$ dikategorikan dukungan keluarga kurang, 56-75 dikategorikan dukungan keluarga cukup, dan 76-100 dikategorikan dukungan keluarga baik. Kategori kemandirian pasien stroke yaitu 0-20 dikategorikan ketergantungan total, 21-60 dikategorikan ketergantungan berat, 61-90 dikategorikan ketergantungan sedang, 91-99 dikategorikan ketergantungan ringan, 100 dikategorikan mandiri.

Data yang diperoleh selanjutnya dianalisis mengunakan uji korelasi Pearson. Uji ini dilakukan untuk mengetahui hubungan dukungan keluarga dengan kemandirian pasien stroke di Instalasi Rehabilitasi Medik Rumah Sakit Dr. Iskak Tulungagung.

Hasil

Distribusi data demografi pasien stroke meliputi jenis kelamin, usia, status 
pernikahan, lama menderita stroke, komplikasi, keluarga yang tinggal serumah dan caregiver.

Tabel 1. Karakteristik demografi responden

\begin{tabular}{|c|c|c|c|}
\hline Demografi & & $\begin{array}{l}\text { Jumlah } \\
\text { (orang) }\end{array}$ & Persenatase (\%) \\
\hline \multirow[t]{2}{*}{ Jenis kelamin } & perempuan & 22 & 38,60 \\
\hline & Laki-laki & 35 & 61,40 \\
\hline \multirow[t]{3}{*}{ Status } & Menikah & 51 & 89.48 \\
\hline & Janda & 5 & 8.77 \\
\hline & Duda & 1 & 1.75 \\
\hline \multirow[t]{3}{*}{ Komplikasi } & Tidak ada & 47 & 82.46 \\
\hline & DM & 6 & 10.53 \\
\hline & Jantung & 4 & 7.02 \\
\hline \multirow[t]{2}{*}{ Tipe keluarga } & Keluarga Inti & 48 & 84.21 \\
\hline & Keluarga Besar & 9 & 15.79 \\
\hline \multirow[t]{3}{*}{ Care giver } & Pasangan & 37 & 64.91 \\
\hline & Anak & 11 & 19.30 \\
\hline & Pasangan, Anak & 9 & 15.79 \\
\hline \multirow[t]{2}{*}{ Usia } & Min & 37 tahun & Rata-Rata \\
\hline & Max & 83 tahun & 58 tahun \\
\hline $\begin{array}{l}\text { Lama Menderita } \\
\text { Stroke }\end{array}$ & 1 bulan & 80 bulan & 18 bulan \\
\hline
\end{tabular}

Berdasarkan Tabel 1 sebagian besar responden berjenis kelamin laki-laki yaitu 35 orang dengan persentase $61,40 \%$, usia responden pasien stroke paling muda adalah 37 tahun sedangkan usia paling tua adalah 83 tahun. Dengan usia rata-rata adalah 58 tahun. Pasien stroke berstatus menikah dengan jumlah 51 orang atau sekitar $89,48 \%$, lama responden terserang stroke adalah rentang 1 bulan hingga 80 bulan. Dengan rata-rata lama terserang 18 bulan.
Sebagian besar responden tidak mempunyai penyakit komplikasi dengan jumlah 47 orang $(82,46 \%)$. Sebanyak $84,21 \%$ responden tinggal bersama keluarga inti yang terdiri dari pasangan dan anak, sedangkan sisanya tinggal bersama keluarga besar yang terdiri dari pasangan, anak, menantu dan cucu, dan responden yang dirawat oleh pasangan dengan jumlah 37 orang atau sekitar $64,91 \%$. 
Dukungan Keluarga Pasien Stroke:

Tabel 2. Distribusi karakteristik dukungan keluarga

\begin{tabular}{cccccc}
\hline Variabel & Jumlah & $\begin{array}{c}\text { SD } \\
+/-\end{array}$ & $\begin{array}{c}\text { Rata- } \\
\text { rata }\end{array}$ & Min & Maks \\
\hline $\begin{array}{c}\text { Dukungan } \\
\text { keluarga }\end{array}$ & 57 & 9,53 & 87,84 & 62 & 100 \\
\end{tabular}

Berdasarkan Tabel 2 dapat diketahui hasil skor variabel dukungan keluarga berdasarkan kriteria yang telah ditentukan. Dari 57 responden, didapatkan skor tertinggi adalah 100 dan skor terendah adalah 67 . Rata-rata dukungan keluarga mendapatkan skor 87,84 yang berarti dukungan keluarga baik.

Tabel 3. Distribusi jenis dukungan keluarga

\begin{tabular}{c|l|c|c|c|c|c|c}
\hline \multirow{2}{*}{ No } & \multirow{2}{*}{$\begin{array}{c}\text { Jenis Dukungan } \\
\text { Keluarga }\end{array}$} & \multicolumn{2}{|c|}{ Baik } & \multicolumn{2}{c|}{ Cukup } & \multicolumn{2}{c}{ Kurang } \\
\cline { 3 - 8 } & & $\mathbf{n}$ & $\%$ & $\mathbf{n}$ & $\%$ & $\mathbf{n}$ & $\%$ \\
\hline 1 & Dukungan Informasional & 5 & 89,47 & 6 & 10,53 & 0 & 0 \\
\hline 2 & Dukungan Penghargaan & 44 & 77,2 & 10 & 17,54 & 3 & 5,26 \\
\hline 3 & Dukungan Instrumental & 5 & 87,72 & 7 & 12,28 & 0 & 0 \\
\hline 4 & Dukungan Emosional & 5 & 89,47 & 6 & 10,53 & 0 & 0 \\
\hline
\end{tabular}

Berdasarkan Tabel 3 di atas diketahui jenis dukungan keluarga yang diterima pasien stroke terbanyak adalah dukungan informasional $(89,47 \%)$ dan dukungan emosional (89,47\%). Jenis dukungan keluarga yang paling sedikit diberikan adalah dukungan penghargaan $(77,2 \%)$.

\section{Kemandirian Pasien Stroke:}

Tabel 4. Frekuensi responden berdasarkan kemandirian

\begin{tabular}{lcclcc}
\hline Variabel & Jumlah & $\begin{array}{l}\text { SD } \\
+/-\end{array}$ & $\begin{array}{l}\text { Rata- } \\
\text { rata }\end{array}$ & Min & Maks \\
\hline Kemandirian & 57 & 14,86 & 81,75 & 15 & 100
\end{tabular}

Pada Tabel 4 di atas ditunjukkan variabel kemandirian berdasarkan kriteria yang telah ditentukan. Dari 57 responden, didapatkan skor tertinggi adalah 100 dan skor terendah 15. Rata-rata mendapatkan skor 81,75 yang berati ketergantungan sedang.

Hubungan Dukungan Keluarga dengan Kemandirian Pasien Stroke:

Tabel 5. Analisis hubungan dukungan keluarga dengan kemandirian

\begin{tabular}{llll}
\hline Variabel & rhitung & $\mathrm{P}$ value & Keterangan \\
\cline { 1 - 1 } $\begin{array}{l}\text { Dukungan } \\
\text { Keluarga }\end{array}$ & 0,737 & 0,00 & $\begin{array}{l}\text { Ada } \\
\text { Hubungan }\end{array}$ \\
\cline { 1 - 1 } Kemandirian & & & Hub \\
\hline
\end{tabular}

Berdasarkan hasil analisis yang tertera pada tabel di atas, diperoleh nilai $r_{h i t u n g}$ sebesar 0,737 dengan nilai signifikansi $p=$ $0,000<0,05$ sehingga diputuskan $H_{1}$ diterima. Dapat diartikan bahwa terdapat hubungan antara dukungan keluarga dan kemandirian dan hubungan ini termasuk kuat. Nilai koefisien yang bertanda positif $(+)$ mempunyai makna apabila dukungan keluarga responden baik, maka responden akan semakin mandiri.

\section{Pembahasan}

Dukungan Keluarga pada Pasien Stroke di Instalasi Rehabilitasi Medik Rumah Sakit Dr. Iskak Tulungagung:

Hasil penelitian dukungan keluarga dari 57 pasien stroke di Instalasi Rehabilitasi Medik Rumah Sakit Dr. Iskak menunjukkan bahwa sebagian besar pasien stroke mendapatkan dukungan keluarga yang baik yaitu sebanyak 50 orang $(87,72 \%)$, dukungan keluarga yang cukup sebanyak 7 orang $(12,28 \%)$, dan tidak ada responden yang berada pada kategori dukungan keluarga kurang. Hasil penelitian ini sejalan 
dengan penelitian Endriyani (2011) tentang dukungan keluarga pada pasien pasca stroke yaitu sebanyak $82,5 \%$ pasien stroke mendapatkan dukungan keluarga "baik" dan 18,5\% pasien mendapatkan dukungan keluarga "cukup". ${ }^{16}$

Dukungan keluarga adalah suatu bentuk hubungan interpersonal yang terdiri atas sikap, tindakan, dan penerimaan terhadap anggota keluarga, sehingga anggota keluarga ada yang memperhatikan. ${ }^{15}$ Dukungan keluarga yang baik pada pasien stroke menunjukkan bahwa keluarga senantiasa ikut berupaya dalam hal penyembuhan dan pemulihan pasien. Data menunjukkan sebanyak 57 keluarga $(100 \%)$ pasien datang bersama keluarga saat menjalani rawat jalan di rehab medik.

Sebanyak $84,21 \%$ pasien stroke tinggal bersama keluarga inti yang terdiri dari ayah, ibu dan anak. Keluarga merupakan bagian dari pasien yang paling dekat dan tidak dapat dipisahkan. Pasien akan merasa senang dan tentram apabila mendapatkan perhatian dan dukungan dari keluarganya, karena dengan dukungan tersebut akan menimbulkan kepercayaan diri untuk menghadapi atau mengelola penyakitnya dengan lebih baik. ${ }^{17}$

Berdasarkan hasil penelitian, pasien stroke yang berstatus menikah sebanyak 51 responden (89,47\%). Status menikah menguntungkan bagi kesembuhan pasien stroke karena mendapatkan perhatian dan perawatan dari pasangan. Caregiver pasien stroke dalam penelitian ini sebagian besar atau 37 orang $(64,91 \%)$ adalah pasangannya. Pasangan hidup memiliki fungsi sebagai supporting dalam berbagai hal misalnya emosi, problem solving, keuangan, maupun pengasuhan. ${ }^{18}$ Pernyataan tersebut sejalan dengan penelitian Pratita, 2012 yang menyatakan dukungan pasangan memiliki pengaruh terhadap kepatuhan proses pengobatan diabetes mellitus. ${ }^{19}$

Jenis dukungan keluarga dibagi menjadi 4 komponen yaitu dukungan informasional, dukungan penghargaan, dukungan instrumental dan dukungan emosional. ${ }^{15}$ Berdasarkan hasil penelitian, jenis dukungan keluarga yang paling banyak diterima adalah dukungan informasional dan dukungan emosional. Selanjutnya dukungan instrumental dan jenis dukungan yang paling sedikit didapatkan adalah dukungan penghargaan.

Jenis dukungan informasional paling banyak diterima pasien stroke dalam penelitian ini yaitu sebanyak 51 responden $(89,47 \%)$. Berbeda dengan penelitian yang dilakukan oleh Wurtuningsih (2012) yang menyimpulkan bahwa dalam dukungan informasional tidak banyak diberikan keluarga karena takut menyebabkan pasien banyak memikirkan tentang penyakitnya. ${ }^{20}$ Dukungan informasional merupakan tanggung jawab bersama termasuk dalam memberikan solusi dari masalah, nasehat atau arahan, dan memberikan informasiinformasi penting yang dibutuhkan pasien dalam proses penyembuhan. Pasien mendapatkan dukungan informasional yang baik karena saat ini sangat mudah mengakses informasi mengenai suatu penyakit dari dokter, perawat, terapis, media cetak dan media elektronik. ${ }^{21}$ Berdasarkan jawaban pertanyaan dalam kuesioner, sekitar 91,23\% keluarga pasien selalu mengingatkan pasien untuk kontrol ke rumah sakit. Selain itu, keluarga pasien stroke di instalasi rehabilitasi medik selalu memberikan nasehat tentang makanan dan gaya hidup yang bisa memicu terjadinya stroke, memberikan informasi upaya penyembuhan, mengingatkan untuk kontrol dan latihan gerak tubuh.

Dukungan emosional meliputi bentuk dukungan keluarga dalam bentuk perhatian, kasih sayang, dan simpati. ${ }^{22}$ Adanya 
dukungan emosional kepada keluarga dapat memberikan perlindungan psikososial dan dukungan terhadap anggotanya. Hasil penelitian menunjukkan bahwa sebanyak 51 responden $(89,47 \%)$ telah mendapatkan dukungan emosional yang baik dari keluarga. Dukungan emosional ditunjukkan keluarga dengan selalu mendengarkan keluhan-keluhan yang diungkapkan pasien, menjaga perasaan agar tidak tersinggung, menghibur saat pasien sedih dan mengungkapkan rasa sayangnya dengan perkataan maupun perbuatan.

Berdasarkan hasil penelitian didapatkan bahwa 50 pasien $(87,72 \%)$ mendapatkan dukungan instrumental yang baik. Hasil ini menunjukkan bahwa keluarga telah menjalankan fungsi perawatan kesehatan dan fungsi ekonomi keluarga dengan baik. Fungsi perawatan kesehatan dapat berupa menyediakan kebutuhan sehari-hari seperti makan, pakaian, tempat istirahat yang nyaman dan membantu pasien minum obat. Fungsi ekonomi keluarga berupa penyediaan finansial yang cukup untuk perawatan dan pengobatan.

Dukungan penghargaan bertindak sebagai umpan balik terhadap apa yang sudah individu lakukan. Hasil penelitian menunjukkan bahwa sebanyak 44 pasien $(77,2 \%)$ telah mendapatkan dukungan dengan baik. Dukungan penghargaan ditunjukkan dengan keluarga selalu memberikan pujian apabila pasien stroke mengalami kemajuan, memberikan semangat dan tetap meminta pendapat kepada penderita atas pemecahan masalah keluarga sehingga pasien tetap merasa dihargai.
Kemandirian Pasien Stroke di Instalasi Rehabilitasi Medik Rumah Sakit Dr. Iskak Tulungagung:

Kemandirian adalah kemampuan diri sendiri dalam mencukupi kebutuhan tanpa memerlukan bantuan dari orang lain. Stroke menyebabkan gangguan yang mempunyai dampak terhadap kemandirian seseorang. Kemandirian seseorang dinilai dengan menggunakan instumen Barthel index yang meliputi 10 aktivitas yaitu makan, mandi, merawat diri, berpakaian, buang air besar, buang air kecil, penggunaan toilet, berpindah, mobilitas dan menggunakan tangga. ${ }^{23}$ Hasil penelitian menunjukkan tingkat kemandirian termasuk dalam kategori sedang dengan means 81,75 .

Prevalensi ketergantungan akibat stroke diperkirakan sekitar 33-460 per 100.000 penduduk. ${ }^{24}$ Hasil penelitian ini, dari 57 pasien stroke mengalami gangguan kemandirian dengan kriteria ketergantungan sedang 41 pasien $(71,93 \%)$, ketergantungan ringan 7 pasien (12,28\%), mandiri 4 pasien $(7,02 \%)$ dan ketergantungan total 1 pasien. Penelitian ini sejalan dengan penelitian Endriyani (2011) bahwa sebagian besar pasien stroke berada pada kondisi ketergantungan sedang sebanyak $70,4 \%$ responden. Menurut Javier (2012), 15\% hingga $30 \%$ penderita stroke memiliki gangguan fisiologis permanen yang mengakibatkan penderitanya mengalami gangguan kemandirian dalam melakukan kegiatan. ${ }^{24}$ Pasien stroke di instalasi rehabilitasi medik rumah sakit Dr. Iskak didominasi rentang usia 56-65 tahun yaitu sebanyak 29 pasien $(50,87 \%)$ dan dihubungkan dengan kondisi kemandirian yang paling banyak ditemui adalah ketergantungan sedang $(71,93 \%)$.

Berdasarkan karakteristik jenis kelamin, jumlah responden laki-laki sebanyak 35 orang $(67 \%)$, sementara perempuan 22 orang $(35,60 \%)$. Hasil penelitian lain juga menyebutkan bahwa laki-laki lebih mudah 
terkena stroke karena mempunyai angka faktor risiko yang lebih tinggi (hipertensi, merokok dan alkohol).12 Namun penelitian Ardi (2010), tidak ditemukan perbedaan kemandirian antara laki-laki dengan perempuan, hal ini disebabkan oleh adanya manifestasi yang dialami pasien stroke yaitu kelemahan fisik memiliki dampak yang sama terhadap ketidakmampuan dalam memenuhi aktivitas sehari-hari seperti makan, mandi, merawat diri, berpindah dan lain-lain. ${ }^{25}$

Hasil penelitian ini menyebutkan bahwa paling banyak (11 responden) dengan lama stroke 12 bulan dengan tingkat kemandirian $72,72 \%$ ketergantungan sedang. Berdasarkan analisis lamanya menderita stroke dan tingkat kemandirian, lama stroke tidak mempengaruhi kemandirian pasien. Menurut Irfan (2012), tingkat keparahan stroke tergantung pada bagian mana yang mengalami kerusakan akibat pengumpulan darah atau perdarahan, besar atau luasnya kerusakan dan seberapa banyak yang mampu ditangani. ${ }^{20}$

Analisis Dukungan Keluarga dengan Kemandirian Pasien Stroke di Instalasi Rehabilitasi Medik Rumah Sakit Dr. Iskak Tulungagung:

Berdasarkan hasil analisis didapatkan hubungan yang signifikan antara dukungan keluarga dan tingkat kemandirian pasien. Hasil penelitian ini sejalan dengan penelitian sebelumnya oleh Rosiana (2012) yang menyebutkan bahwa sebagian besar responden telah memperoleh dukungan keluarga yang baik. Kesesuaian penelitian ini dengan penelitian sebelumnya dapat ditunjukkan bahwa semakin tinggi atau semakin baik dukungan keluarga, maka semakin patuh pasien stroke dalam menjalani rehabilitasi dan peningkatan kemandirian. ${ }^{26}$

Menurut peneliti, apabila keluarga memberikan dukungan yang baik kepada pasien stroke maka kemandirian pasien stroke akan meningkat. Berdasarkan hasil kuesioner dalam penelitian ini keluarga selalu optimis pasien stroke akan pulih kembali dengan melakukan latihan dan rajin kontrol. Sehingga pasien stroke akan merasa termotivasi dan semangat melakukan latihan dan menjalani pengobatan. Dukungan keluarga terbukti berhubungan dengan menurunnya mortalitas, lebih mudah sembuh dari sakit, fungsi kognitif, fisik dan kesehatan emosi. ${ }^{15}$

Penelitian lain juga menyatakan terdapat hubungan peran keluarga dalam merawat dan memotivasi pasien pasca stroke dengan kepatuhan penderita dalam mengikuti pengobatan dan pelaksanaan rehabilitasi. ${ }^{27}$ Keluarga adalah unit yang paling dekat dengan pasien yang memiliki peran sebagai motivator atau pendukung serta sebagai edukator bagi anggota keluarga lain dalam melaksanakan program kesehatan secara mandiri. Jika tidak ada dukungan dari keluarga, maka keberhasilan pemulihan (rehabilitasi) semakin kecil. Oleh karena itu, dukungan keluarga sangat diperlukan dalam mendampingi pasien stroke mengikuti rehabilitasi. ${ }^{15}$

\section{Kesimpulan}

Penelitian ini menyimpulkan bahwa dukungan keluarga pasien stroke di Instalasi Rehabilitasi Medik Rumah Sakit Dr. Iskak mayoritas memiliki dukungan keluarga yang baik yaitu sebanyak $87,72 \%$. Sebagian besar kemandirian pasien stroke masuk dalam klasifikasi ketergantungan sedang yaitu sebanyak $71,93 \%$. Terdapat hubungan positif dukungan keluarga dengan kemandirian pasien stroke, sehingga semakin baik dukungan keluarga maka semakin mandiri pasien stroke. 
Saran

1. Bagi Petugas Kesehatan

Diharapkan petugas kesehatan dapat meningkatkan peran dalam berkolaborasi dengan keluarga dan pasien dalam melakukan latihan dan menjaga mobilitas seperti melakukan latihan rentang gerak. Keluarga dan pasien dapat saling memberikan dukungan dalam meningkatkan fungsi fisiologis tubuh pasien stroke dirumah.

2. Bagi Peneliti Selanjutnya

a. Diharapkan bagi peneliti selanjutnya untuk mengembangkan penelitian tentang hubungan dukungan keluarga dengan kemandirian pasien stroke dengan jumlah sampel yang seimbang antara wanita dan pria sehingga terlihat jelas hubungan yang dihasilkan.

b. Diharapkan dapat mengembangkan penelitian selanjutnya yang berhubungan dengan kemandirian pasien stroke dengan faktor-faktor lain yang belum pernah diteliti seperti kondisi ekonomi, jenis stroke dan tingkat kecacatan.

\section{Daftar Pustaka}

1 Gillen G. Stroke rehabilitation: A function-based Approach. $4^{\text {th }}$ Edition. United States of America: Elsevier. 2015.

2 National Institute of Neurological Disorders and Stroke. Brain Basics: Preventing Stroke. (Online). 2009.

3 BKKBN. (Online). 2009. http://nad.bkkbn.go.id/. $\quad$ Diakses November 2015.

4 CDC. Stroke Maps and Data Sources. (Online). 2014. http://www.cdc.gov/stroke/maps_data.h tml. Diakses November 2015.

5 World Health Organization. Recommendations on Stroke
Prevention, Diagnosis and Therapy. Stroke. 2008; 40:1407-1431.

6 Stroke Association. Impact of Stroke (Stroke Statistics). (Online). 2015.http://www.strokeassociation.org/ STROKEORG/AboutStroke/Impact-ofStroke-Stroke

statistics_UCM_310728_Article.jsp\#.VI G6DdLhDIU. Diakses November 2015.

7 Widjaja H, Putra IBK, Nuartina AABN. Neurorestorasi Pasca-stroke: Harapan Baru Penderita Stroke. CDK-227. 2015; 42(4):257- 261

8 Cameron et al. Randomized Clinical Trial of the Timing It Right Stroke Family Support Program:Research Protocol. BMC. 2014; 14:18.

9 Langhorne P, Bernhardt J, Kwakkel G. Stroke Rehabilitation. Elsevier. 2011; 377(9778):1693-702.

10 Mu'tadin Z. Pengantar Pendidikan dan IImu Perilaku Kesehatan. Yogyakarta: Andi Offset. 2002.

11 Mulyatsih E dan Ahmad A. Stroke; Petunjuk Perawatan Pasien Pasca Stroke di Rumah. Jakarta: FK Universitas Indonesia. 2010.

12 KEMENKES. Presiden Resmikan RS Pusat Otak Nasional, (Online). 2014.http://www.depkes.go.id/article/vie w/201407200001/presiden-resmikan-

rs-pusat-otak-nasional.html. Diakses November 2014.

13 Smeltzer C, Suzanne, Brunner \& Suddarth. Buku Ajar Keperawatan Medikal Bedah. EGC: Jakarta. 2002.

14 Setiadi. Konsep dan Proses Keperawatan Keluarga. Edisi kedua. Yogyakarta: Graha llmu. 2010.

15 Friedman M. Buku Ajar Keperawatan keluarga : Riset, Teori, dan Praktek. Edisi kelima. Jakarta: EGC. 2010.

16 Endriyani L. Hubungan Dukungan Keluarga dengan Kemandirian Activities Of Daily Living Pasien Post 
Stroke di RSU PKU Muhammadiyah Bantul. 2011.

17 Nainggolan. Dasar-dasar Keperawatan Kesehatan Masyarakat. Jakarta: EGC. 2012.

18 Papalia DE, et al. Human Development (PsikologiPerkembangan). Jakarta: Kencana. 2009.

19 Pratita N. Hubungan Dukungan Pasangan dan Health Locus Of Control dengan Kepatuhan dalam Menjalani Proses Pengobatan pada Penderita Diabetes Melitus Tipe-2. Jurnal Mahasiswa IImiah Universitas Brawijaya. 2012; 1(1).

20 Wurtuningsih B. Dukungan Keluarga pada Pasien Stroke di Ruang Saraf RSUP Dr. Kariadi Semarang. Med Hosp. 2012; 1(1): 57-59.

21 Nurkhayati D. Gambaran Dukungan Sosial Keluarga pada Pasien Gagal Ginjal Kronik yang Menjalani Hemodialisis Di Instalasi Dialisis RS Dr. Sardjito. Yogyakarta: Universitas Gadjah Mada. 2005.

22 Kaakinen JR, Hanson SMH. Theoretical Foundations for Family Health Nursing Practice. Di dalam: Bomar PJ (Editor). Promoting Health in Families: Applying Family Research and Theory to Nursing Practice. 3. Philadelphia: Saunders. 2004. P 93116.
23 Suparyanto. Konsep Dukungan Keluarga. (Online) . 2012. http://drsuparyantoblogspot.com/2012/0 3/konsep-dukungan-keluarga.html. Diakses 28 September 2014.

24 Javier F. Determining Quality of Life in Stroke Survivors. Expert Rev Pharmacoecon Outcomes Res. 2012; 12(2):199-211.

25 Ardi. Analisis Hubungan Ketidakmampuan Fisik Dan Kognitif Dengan Keputusasaan Pada Pasien Stroke Di Makassar. Depok: FIK UI. 2011.

26 Rosiana E. Hubungan Dukungan Keluarga dengan Kepatuhan Menjalani Fisioterapi pada Klien Pasca Stroke di Instalasi Rehabilitasi Medik RSUD Sleman Yogyakarta. Yogyakarta: Universitas Respati. 2012. P 11-15.

27 Kosassy SM. Hubungan Peran Keluarga Dalam Merawat dan Memotivasi Penderita Pasca Stroke dengan Kepatuhan Penderita Mengikuti Rehabilitasi di Unit Rehabilitasi Medik RSUP. Dr. M. Djamil Padang tahun 2011. Padang: Universitas Andalas. 2011. 